\title{
Strategi Hubungan Masyarakat Lembaga Penyiaran Publik Televisi Republik Indonesia Jambi dalam Mempromosikan Program Acara
}

\author{
Nopita Sari, Mila Wahyuni, Eka M. Taufani \\ UIN Sulthan Thaha Saifuddin Jambi \\ Email:milawahyuni@uinjambi.ac.id
}

\begin{abstract}
Abstrak: Penelitian ini dilatarbelakangi oleh fenomena yang terjadi pada bidang Hubungan Masyarakat (HUMAS) lembaga Penyiaran Publik Televisi Republik Indonesia (LPP TVRI) Jambi. Strategi diperlukan oleh TVRI Jambi seiring zaman berubah dimana minat penonton televisi semakin menuruh dikarenakan persaingan baik dengan televisi swasta maupun media baru. Penontoh mengikuti gaya yang ada nilai. Oleh karena itu perlu adanya seorang Publik Relations supaya memperluas pengetahuan masyarakat tentang program program apa saja yang ada di TVRI guna meningkatkan eksistensi TVRI Jambi. Penelitian ini menggunakan metode kualitatif dengan pendekatan studi kasus. Metode pengumpulan data yang digunakan berupa observasi, dokumentasi, dan wawancara dengan teknik analisis data yaitu reduksi data, penyajian data, dan verifikasi data. Hasil penelitian ini penulis menemukan bahwa Strategi Publik Relations dalam mempromosikan program acara TVRI Jambi untuk meningkatkan kualita program acara TVRI di mata masyarakat agar lebih memahami dan mengetahui siaran siaran di TVRI Jambi oleh sebab itu Publik Relations sendiri mengunakan strategi komunikasi Strategi public relations,komunkasi,periklanan, promosi penjualan, publiksitas ,corporate design Adapun kendala Publik Relations dalam mempromosikan program acara Ipp tvri di jambi, lemahnya sumber daya manusia, Upaya pr dalam mempromosikan program acara LPP TVRI Jambi menjalin kerja sama dengan instansi lain.
\end{abstract}

Kata-kata kunci: hubungan masyarakat, TVRI Jambi, promosi, program acara.

\section{A. Pendahuluan}

Unit Hubungan Masyarakat atau humas menyangkut kepentingan setiap organisasi yang bersifat komersial maupun yang non komersial. Kehadirannya tidak bisa dicegah, terlepas dari kita menyukainya atau tidak. Dengan demikian, humas itu senantiasa muncul di luar kendali. Sebenarnya apa yang biasa disebut sebagai PR atau humas terdiri dari semua bentuk komunikasi yang terselenggara 
antara organisasi yang bersangkutan dengan siapa saja yang menjalin kontak dengannya. Setiap orang pada dasarnya juga selalu mengalami humas, kecuali jika ia adalah sejenis tarzan yang tidak bertemu atau menjalin kontak dengan manusia lainnya. ${ }^{1}$

Publik relations merupakan bagian dari tugas penerangan, baik pemerintah maupun swasta karena penerangan merupakan bagian dari komunikasi sosial dan komunikasi yang harus berkembang antara pemerintah dan rakyat,antara rakyat,kelompok masyarakat dan kelompok masyarakat lainnya. Setiap pembangun atau instansi ingin mencapai tujuan yang telah di gariskan sebelumnya, melaksanakan upaya-upaya dan langkah-langkah tertentu. Tentu saja keberhasilan ini tidak dapat dicapai berdasarkan kemampuan yang ada. Karena selain dari pada itu masih diperlukan pengertian, peran serta (partisipasi) publiknya (internal, eksternal). ${ }^{2}$

Publik Relations mempunyai ikatan yang erat dengan berbagai media, baik media cetak seperti surat kabar, majalah, dan tabloid, serta media elektronik seperti televisi, radio, ataupun internet. Karena melalui dan melibatkan media itulah, Bidang Public Relations dapat melakukan kegiatan sesuai bidangnya adalah kegiatan media relations seperti Konferensi Pers, Press Breafing, Press Tour, Press Release, Special Event, Press Luncheon, Wawancara Pers. Kegiatan media relations dapat dilakukan dengan baik untuk menyalurkan sebuah pesan melalui pers kepada audience secara efektif, dan dapat tersebar luas apabila disalurkan melalui media dengan baik. dalam Al Qur'an menganjurkan, bahwa sesuatu informasi itu harus disampaikan, jika tidak disampaikan dianggap tidak melaksanakan amanah. Sebagaimana yang dijelaskan dalam surah Al-Maidah ayat 67 berikut ini :

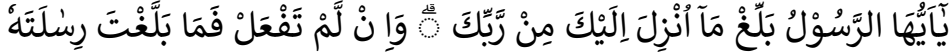

\footnotetext{
${ }^{1}$ Frank Jefkins, Public relations, (Jakarta: Gelora aksara pratama,1995), h.8

${ }^{2}$ H.A.W.Widjaja, Komunikasi dan hubungan masyarakat, (Jakarta: Bumi Aksara, 2010), h.3
} 
“Hai Rasul, sampaikanlah apa yang diturunkan kepadamu dari tuhanmu. dan Jika tidak kamu kerjakan (apa yang diperintahkan itu, berarti) kamu tidak menyampaikan amanat-nya". (QS. Al-Maidah : 67). ${ }^{3}$

Televisi Republik Indonesia (TVRI) adalah stasiun televisi pertama di Indonesia yang mengudara pada tanggal 24 Agustus 1962. TVRI berstatus sebagai Lembaga Penyiaran Publik bersama Radio Republik Indonesia. Siaran perdananya dalam format hitam-putih, menayangkan Upacara Peringatan Hari Kemerdekaan Republik Indonesia ke-17 dari Istana Negara Jakarta. Liputan besar yang pertama ditayangkan TVRI adalah Asian Games yang diselenggarakan di Jakarta, pada tahun 1962.

Sebagai satu-satunya stasiun televisi pada saat itu, TVRI memonopoli siaran televisi di Indonesia hingga tahun 1989, ketika didirikan televisi swasta pertama RCTI di Jakarta dan SCTV pada tahun 1990 di Surabaya.TVRI Nasional saat ini mengudara di seluruh wilayah Indonesia dengan sistem siaran analog dan sistem siaran digital.

Selain itu juga persaingan bisnis per televisian di Indonesia khususnya di kota jambi dewasa ini yang semakin ketat terutama terhadap perusahaan swasta. seperti berbagai tv swasta ialah kompas tv,jek tv,jambi tv dan lainnya.dalam mendapatkan tempat dimata costumer diantaranya adalah program program yang menarik dan membangun dimana mereka bersaing untuk memberikan pelayanan dan produk yang terbaik bagi costumer serta berusaha untuk mempertahankan eksistensinya dibenak costomer.

Kepuasan customer merupakan salah satu tujuan utama yang ingin dicapai oleh perusahaan, khususnya di kota jambi yang merupakan kota berat dalam menghadapi persaing-pesaingnya dalam mendapatkan tempat dimata customer yang notabene sebagian besar dari pengguna media sosial. hlm, 120

${ }^{3}$ Dewan Penerjemah, Al-Qur'an dan Terjemahnya, (Jakarta: CV Darus Sunnah, 2002), 
Sarana pertelevisian TVRI Jambi telah mengalami perkembangan yang mengesankan dari tahun ketahun baik secara kuantitatif(daya jangkau aksebilitas dan kapasitas), maupun secara kualitatif (kecanggihan teknologi,efesiensi dan mutu pelayanan). Hal ini dapat dibuktikan setiap tahun TVRI Jambi mengeluarkan produk terbaru seperti beranda budaya,kuis ceria, Jambi hari ini, mari bercerita dan program-program menarik lainnya yang dapat memuaskan keinginan customer yang menginginkan inovasi terbaru dalam memenuhi kebutuhan pertelevisian dan akan meluncurkan program terbarunya dalam waktu dekat ini yaitu serba serbi ramadhan.

TVRI Nasional siaran analog mengudara secara berjaringan, TVRI Daerah siaran analog mengudara mulai jam 08.00-10.00 WIB dan 16.00-18.00 WIB. Meskipun demikian, atas alasan kewajiban untuk merelai TVRI Nasional yang sedang menyiarkan secara langsung pertandingan olahraga, acara kenegaraan RI, acara spesial live event dan Breaking News, maka TVRI Daerah pun wajib mengurangi jam siarannya, bahkan hingga tidak bersiaran sama sekali.

Wilayah Provinsi Jambi yang berbukit-bukit menyebabkan masih banyak daerah blank spot atau daerah yang tidak dapat menerima signal siaran TVRI Jambi. Pada umumnya mereka menggunakan antena parabola untuk menangkap siaran televisi melalui satelit. Akibatnya informasi pembangunan Jambi yang disiarkan melalui TVRI Jambi tidak diketahui oleh masyarakat di pelosok desa. Untuk kepentingan penyebarluasan informasi pembangunan di seluruh wilayah Jambi maka Pemerintah Provinsi Jambi telah menyewa transponder Telkom guna memperluas jangkauan siaran TVRI Jambi. ${ }^{4}$

Siaran pertelevisian TVRI Jambi menyelenggarakan siarannya dalam bidang-bidang pendidikan, pengajaran, penerangan maupun hiburan. Bidangbidang tersebut tidak menutup kemungkinan untuk menyiarkan siaran-siaran yang bersifat komersil untuk kepentingan lembaga tersebut.

\footnotetext{
${ }^{4}$ http://wikipedia.Profil LPP TVRI stasiun jambi 2010.pdf.diakses pada tanggal 18 november 2019 pukul 19.45 wib s/d selesai
} 
TVRI Jambi memiliki kelemahan lain yang telah diketahui oleh masyarakat luas seperti, masalah pendengarnya yang terlalu tersegmentasi dan frekuensi serta itensitas pendengar tidaklah setinggi penonton televise lainnya. Untuk mengurangi kelemahan tersebut, perlulah menciptakan sebuah karya yang kreatif dan inovatif dan mendapatkan feedback sesuai harapan. Sehingga terjadi proses kerjasama atas program, produk atau jasa yang dimiliki sebuah lembaga. Salah satu caranya adalah dengan melibatkan pers dan menjalin hubungan yang baik dengan media serta menambahkan elemen-elemen suara atau efek, program acara serta kegiatan yang dapat menjadi daya tarik pendengarnya serta memperbanyak fasilitas-fasilitas yang diberikan kepada masyarakat atau mitra kerjanya dengan menggunakan strategi publik relation dan kegiatan publik relation diharapkan mampu untuk meningkatkan pendengar di media tersebut.

Media relation sangat penting bagi organisasi. Dalam menjalin komunikasi dan relasi dengan publiknya, mereka menggunakan media untuk menjaga reputasi dari perusahaan atau organisasi mereka. Oleh sebab itu penting bagi seorang PR untuk memahami seluk beluk media massa. Karena akhir-akhir ini media massa di Indonesia mengalami perubahan yang signifikan sejak era reformasi bergulir,ditambah lagi dengan media baru sedang berkembang pesat saat ini.Untuk mencapai tujuannya, seorang PR membutuhkan media massa agar dapat menjangkau seluruh stakeholder-nya yang bersifat heterogen dan berada ditempat yang terpisah. Untuk itu dibutuhkan hubungan baik antara PR dengan wartawan agar pesan yang dibuat oleh PR dapat dipublikasikan dan disebarkan kepada khalayak.

Strategi publik relations yang dilakukan LPP TVRI Jambi dengan cara melakukan komunikasi yang baik dan efektif terhadap wartawan dan lembaganya, mengadakan promosi dan kerja sama dengan berbagai pihak untuk mengenalkan kepada masyarakat fasilitas yang dimiliki oleh LPP TVRI tersebut. Promosi yang dilakukan dalam bidang publikasi dapat dilakukan dengan beberapa media cetak maupun media elektronik. Serta menciptakan 
kepercayaan dan menjaga eksistensi sebuah lembaga. Apabila sebuah lembaga telah memiliki reputasi baik dimata publik maka dengan sendirinya opini publik akan terbentuk. Penulisan opini yang dikonsumsi oleh masyarakat menyangkut lembaga yang dipublikasikan melalui berbagai media akan menentukan kualitas program Ipp tvri tersebut.

Program acara ditampilkan oleh stasiun penyiaran untuk memenuhi kebutuhan atau yang diinginkan audience-nya. Program yang ditayangkan stasiun televisi tidak harus diproduksi sendiri melainkan dapat bekerja sama dengan pihak luar stasiun televisi, misalnya dengan production house atau instansi pemerintah dan swasta. Pada umumnya pihak perencanaan siaran mengatur jadwal penayangan satu program televisi berdasarkan perkiraan kecenderungan menonton program tersebut.

Karakteristik Suatu program televisi selalu mempertimbangkan agar program acara tersebut digemari oleh penonton. Semakin banyak penonton maka program semakin sukses pula pada kepentingan komersialnya. Berdasarkan uraian diatas, maka masalah penelitian ini adalah bagaimana strategi Humas mempromosikan program acara TVRI Jambi serta upaya dalam mengatasi semua hambatan, mempromosikan program acara di Lembaga Penyiaran Publik TVRI Jambi. Metode penelitian adalah kualitatif dengan pendekatan studi kasus. Adapun yang menjadi informan utama penelitian ini yaitu Kepala Stasiun TVRI Jambi, staf Humas atau Public Relation dan Kepala Unit Pelayanan dan Pemasaran serta salah satu staf Customer Service, yang menjadi informan utama dalam mengali dan mengumpulkan informasi mengenai Perusahaan daerah LPP TVRI Kota Jambi.

\section{B. Strategi Promosi Hubungan Masyarakat (Public Relation)}

Sebelum mengemukakan definisi public relations, secara etimologis Public relations terdiri dari dua buah kata, yaitu public dan relations. Dalam Bahasa Indonesia, kata pertama berarti publik dan kata kedua berarti hubungan-hubungan dengan publik. 
Untuk memahami dengan benar apa yang di maksud dengan arti tersebut dapatlah dijelaskan pengertian dari masing-masing kata yang membentuknya.$^{5}$

Selain itu Menurut Onong Uchyana Efendi, "[S]trategi pada hakikatnya adalah perencanaan (planning) dan manajemen untuk mencapai tujuan tersebut, strategi tidak berfungsi sebagai peta jalan yang hanya memberi arah saja, melainkan harus mampu menunjukkan bagaimana teknik operasionalnya". ${ }^{6}$ Sedangkan dalam manajemen atau organisasi, strategi diartikan kiat, cara dan taktik utama yang dirancang secara sistematik untuk melaksanakan fungsi manajemen yang terarah pada tujuan organisasi. ${ }^{7}$

Dalam konteks pengajaran, Menurut Gagne (1974) mengatakan bahwa: "[S]trategi adalah kemampuan internal seseorang untuk berffikir, memecahkan masalah, dan mengambil keputusan". ${ }^{8}$ Artinya, bahwa proses pembelajaran akan menyebabkan peserta didik berpikir secara unik untuk dapat menganalisis, memecahkan masalah di dalam mengambil keputusan. Peserta didik akan mempuyai kontrol tingkat tinggi, yaitu analisis yang tajam, tepat, dan akurat.

Berdasarkan pengertian-pengertian diatas, penulis menyimpulkan bahwa:

[K] eseluruhan pengertian strategi diatas merujuk pada aspek perencanaan yang cermat, terukur dan dipersiapkan melalui mekanisme yang benar. Pengertian strategi tersebut diterapkan pada berbagai disiplin ilmu, termasuk juga dalam proses membina ibadah. Artinya strategi-strategi yang direncanakan dalam membina ibadah dapat berjalan dengan terukur dan cermat dan mendapatkan tujuan yang diharapkan, dengan memanfaatkan segala kemampuan yang dimiliki oleh sumber daya yang ada, sehingga tujuan yang diinginkan tercapai dengan maksimal.

Secara umum Hubungan Masyarakat atau Public relations adalah proses interaksi dimana public relation menciptakan opini publik sebagai input yang menguntungkan kedua belah pihak, dan menanamkan pengertian, menumbuhkan motivasi dan partisipasi publik, bertujuan menanamkan keinginan baik, kepercayaan saling adanya pengertian, dan citra yang baik dari publiknya. Sering sekali dikemukakan betapa sulitnya untuk mendefinisikan pengertian dari public relations secara memuaskan dan bisa diterima oleh semua kalangan, sekaligus bisa mendeskripsikannya

${ }^{5}$ Suhandang, Definisi public relations(Jakarta:2004) h.29

${ }^{6}$ Onong Uchyana, Ilmu Komunikasi Teori dan Praktek (Bandung: PT. Remaja Rosdakarya, 1992), cet ke-4, hlm. 32 .

${ }^{7}$ Hadari Nawawi, Manajemen Strategi Organisasi Non Profit Bidang Pemerintahan Ilustrasi di bidang Pendidikan (Yogyakarta: Gadjah Mada Universitas Press, 2000), hlm. 147.

${ }^{8}$ Iskandarwassid dan Danang Sunendar, Strategi pembelajaran bahasa, (Bandung: Remaja Rosdakarya, 2001), hlm 3. 
secara utuh. Meskipun definisi dari public relations telah banyak dikemukakan oleh para ahli, tetapi istilah dari public relations itu sendiri sering diartikan menjadi "hubungan masyatakat (humas)".

Sebenarnya bisa dikatakan bahwa penggunaan istilah hubungan masyarakat ini tidak begitu tepat. Arti kata "public" dalam public relations berbeda dengan kata "masyarakat" dalam hubungan masyarakat. Istilah masyarakat bisa dikatakan terlalu luas, sedangkan public (publik) hanyalah merupakan bagian dari masyarakat tersebut. Public merupakan sekumpulan orang atau kelompok dalam masyarakat yang memiliki kepentingan atau perhatian yang sama terhadap sesuatu hal.

Didalam sebuah strategi, di perlukan adanya tahapan-tahapan untuk menjalankan strategi, diantaranya yaitu: ${ }^{9}$

\section{1). Perumusan Strategi}

Langkah pertama yang harus dilakukan adalah merumuskan strategi yang dilakukan, sudah termasuk didalamnya adalah pembangunan tujuan, mengenai dan ancaman eksternal, menetapkan suatu objektifitas, menghasilkan strategi alternative, dan memilih strategi untuk dilaksanakan. Dalam perumusan strategi juga ditentukan suatu sikap untuk memutuskan, memperluas, menghindari atau melakukan suatu keputusan dalam proses kegiatan.

2). Implementasi Strategi

Setelah merumuskan dan memilih strategi yang telah ditetapkan maka langkah berikutnya melaksanakan strategi yang ditetapkan tersebut. Dalam tahap pelaksanaan strategi yang telah dipilih sangat membutuhkan komitmen dan kerjasama dari unit, tingkat dan anggota organisasi, dalam pelaksanaan strategi, maka proses formulasi dan analisis strategi hanya akan menjadi impian yang jauh dari kenyataan, implementasi strategi bertumpu pada alokasi dan pengorganisasian sumber daya yang ditampakkan melalui penetapan struktur organisasi dan mekannisme kepemimpinan yang dijalankan bersama.

\section{3). Evaluasi Strategi}

Tahap yang terakhir dari menyusun strategi adalah evaluasi strategi. Evaluasi strategi sangat diperlukan karena keberhasilan yang dicapai dapat

\footnotetext{
${ }^{9}$ Fred R David, Manajemen Strategi Konsep, (Jakarta: Prehalindo, 2003), hlm 3.
} 
diukur kembali menetapkan tujuan berikutnya. Evaluasi menjadi tolak ukur strategi yang akan dilaksanakan kembali oleh suatu organisasi dan evaluasi sangat diperlukan untuk memastikan sasaran yang dinyatakan telah dicapai. Ada tiga macam kegiatan yang mendasar untuk mengevaluasi strategi yaitu:

a) Meninjau faktor-faktor internal dan eksternal yang menjadi dasar strategi. Adanya perubahan yang ada akan menjadi suatu hambatan dalam mencapai sebuah tujuan, begitu pula dengan faktor internal yang diantaranya strategi tidak efektif atau hasil implementasi yang buruk dapat berakibat buruk pula bagi hasil yang akan dicapai.

b) Mengukur prestasi (membandingkan dengan kenyataan). Proses dapat dilakukan dengan menyelidiki penyimpangan dari rencana, mengevaluasi prestasi individual, dan menyimak yang dibuat kearah pencapaian sasaran yang dinyatakan. Kriteria untuk mengevaluasi strategi diukur dan mudah di buktikan. Kriteria yang meramalkan hasil lebih penting dari pada kriteria yang mengungkapkan yang terjadi.

c) Mengambil tindakan korektif untuk memastikan bahwa prestasi sesuai dengan rencana. Dalam hal ini tidak harus berarti bahwa strategi ada yang ditinggalkan atau harus merumuskan strategi yang baru. Tindakan korektif diperlukan bila tindakan atau hasil yang ditetapkan tidak sesuai dengan apa yang dibayangkan semula atau pencapaian yang diharapkan.

Pengertian Strategi secara umum adalah pendekatan secara keseluruhan yang berkaitan dengan pelaksanaan gagasan, perencanaan, dan eksekusi sebuah aktivitas dalam kurun waktu tertentu. Strategi berasal dari kata yunani strategia (stratos = militer; dan ag = memimpin), strategi dapat diartikan sebagai suatu rencana untuk pembagian dan penggunaan kekuatan dan material pada daerahdaerah tertentu untuk mencapai tujuan tertentu. secara umum dapat diartikan sebagai rencana yang disusun oleh perusahaan untuk mencapai tujuan yang telah ditentukan.

Stephen Robbins mendefinisikan strategi merupakan:

[P]enentu jangka panjang perusahaan dan memutuskan arah tindakan serta mendapatkan sumber-sumber yang dibutuhkan untuk mencapai tujuan, Berfikir strategis meliputi tindakan memperkirakan atau membangun tujuan masa depan yang diinginkan, menentukan kekuatan-kekuatan yang akan membantu 
atau yang akan membuat atau yang akan menghalangi tercapainya tujuan, serta merumuskan rencana untuk mencapai keadaan yang diinginkan. ${ }^{10}$

Berdasarkan prespektif pertama, strategi dapat difenisikan sebagai program untuk menentukan dan mencapai tujuan organisasi dan mengimplementasikan misinya. Maksudnya adalah bahwa para manajer memainkan peran yang aktif, sadar dan rasional dalam merumuskan strategi organisasi. Dalam lingkungan yang turbulen dan selalu mengalami perubahan, pandagan ini lebih banyak diterapkan. Berdasarkan prespektif kedua, strategi didefinisikan sebagai pola tanggapan atau respon organisasi terhadap lingkungannya sepanjang waktu. ${ }^{11}$

Untuk mencapai tujuan yang diharapkan, maka sebuah perusahaan atau lembaga harus memiliki strategi untuk mencapainya. Keputusan yang paling taktikal akan membangun keseimbangan promosi yang benar-benar nyata bila pandangan strategis menggarisbawahi segala aktivitas. Tujuan utama dari strategi itu sendiri adalah kepuasan customer karena hal itu merupakan tujuan dari semua perusahaan. Strategi adalah sessuatu yang konpetitif ,tujuan srategi adalah untuk membedakan sebuah perusahaan dari pesaingnya agar pelanggan memperoleh pilihan yang jelas dan membangun preferensi yang berulang. ${ }^{12}$

Promosi merupakan salah satu variabel marketing mix yang digunakan oleh perusahaan untuk mengadakan komunikasi dengan pasarnya. Promosi juga sering dikatakan sebagai "proses berlanjut" karena dapat menumbulkan rangkaian kegiatan selanjutnya dari perusahaan.

Djaslim Saladin dan Yevis Marty Oesman berpendapat bahwa "Promosi adalah suatu komunikasi informasi penjual dan pembeli yang bertujuan untuk merubah sikap dan tinakah laku pembeli, yang sebelumnya tidak mengenal menjadi mengenal sehingga menjadi pembeli dan mengingat produk tersebut". Kemudian menurut Cannon, "promosi adalah mengomunikasikan informasi antara penjual dan pembeli potensial atau orang lain dalam saluran untuk memengaruhi sikap dan perilaku".

${ }^{10}$ Morisson, Manajemen Public Relations Strategi Menjadi Humas Profesional (Jakarta: Kencana Perenada Media Grup, 2010), hlm. 152

${ }^{11}$ Tjiptono ,konsep strategi ( Jogjakarta:1997) h.3

${ }^{12}$ Frenk jefkins,strategi public relations edisi kedua, (Jakarta: Gelora aksara pratama,1995), h.10. 
Promosi merupakan alat komunikasi dan penyampaian pesan yang dilakukan baik oleh perusahaan maupun perantara dengan tujuan memberikan informasi mengenai produk, harga dan tempat. Informasi itu bersifat memberitahukan, membujuk, mengingatkan kembali kepada konsumen, para perantara atau kombinasi keduanya. Dalam promosi juga, terdapat beberapa unsur yang mendukung jalannya sebuah promosi tersebut yang biasa disebut bauran promosi.

Promosi Philip Kotler mendefinisikan pemasaran sebagai suatu proses perencanaan dan menjalankan konsep, harga, promosi, serta diatribusi sejumlah barang dan jasa, untuk menciptakan pertukaran yang mampu memuaskan tujuan individu dan organisasi. Dalam pemasaran terdapat strategi yang disebut Bauran Promosi yang mempunyai peranan penting dalam mempengaruhi konsumen untuk membeli atau jasa yang ditawarkan oleh perusahaan.

Bauran promosi merupakan gabungan dari berbagai jenis promosi yang ada untuk suatu produk yang sama agar hasil dari kegiatan promo yang dilakukan dapat memberikan hasil yang maksimal. Sebelum melakukan promosi sebaiknya dilakukan perencanaan matang yang mencakup bauran promosi sebagai berikut :

1. Iklan seperti iklan koran, majalah, radio, katalog, poster, dll.

2. Promosi dari mulut ke mulut dengan memaksimalkan hal-hal positif.

3. Promosi penjualan dengan ikut pameran, membagikan sampel, dll.

4. Public relation / PR yang mengupayakan produk diterima masyarakat.

5. Personal selling / penjualan personil yang dilakukan tatap muka langsung.

Bicara soal manfaat, kontribusi advertising bagi perusahaan jelas tidak dapat disepelekan. Bahkan, periklanan memegang kunci penting, terutama dalam hal pelaksanaan promosi perusahaan. Dalam aktivitas perusahaan, advertising/periklanan merupakan bagian dari promotion mix/ bauran promosi.

Adapun bauran promosi menurut Plilip Kotler yang tercantum dalam buku adalah sebagai berikut . pertama Periklanan (Advertising) Periklanan adalah semua bentuk penyajian nonpersonal, promosi ide-ide, promosi barang atau jasa yang dilakukan oleh sponsor yang dibayar, kedua Promosi Penjualan (Sales Promotion) Promosi penjualan adalah variasi insentif jangka pendek untuk merangsang pembelian atau penjualan suatu produk atau jasa, ketiga Hubungan masyarakat dan Publisitas (Public Relation and Publicity) Hubungan masyarakat adalah suatu usaha (variasi) dari 
rancangan program guna memperbaiki, mempertahankan, atau melindungi perusahaan atau citra produk, keempat Penjualan Personal (Personal Selling) Penjualan pribadi atau tatap muka adalah penyajian lisan dalam suatu pembicaraan dengan satu atau beberapa pembeli potensial dengan tujuan untuk melakukan penjualan, kelima Pemasaran Langsung (Direct Marketing Komunikasi secara langsung yang digunakan dari mail, telepon, fax, e-mail, atau internet untuk mendapatkan tanggapan langsung dari konsumen secara jelas.

Suatu program televisi selalu mempertimbangkan agar program acara tersebut digemari oleh penonton. Semakin banyak penonton maka program semakin sukses pula pada kepentingan komersilnya. Untuk itu ada empat hal yang mendasari karakter suatu program yaitu. Pertama Product, berhubungan dengan materi program yang dipilih harus bagus dan bisa menarik penonton. Untuk itu televisi komersial banyak mengangkat materi yang unik, sensasional ataupun yang sedang menjadi trend di masyarakat, kedua Price, yaitu biaya yang harus dikeluarkan untuk memproduksi atau membeli suatu program, sekaligus menentukan tarif bagi pemasang iklan, ketiga Place, yaitu ada waktu siaran yang sekiranya tepat untuk program tersebut. Pemilihan waktu siar yang tepat akan membantu keberhasilan program tersebut, keempat Promotion, yaitu bagaimana memperkenalkan kemudian menjual acara itu sehingga dapat mendatangkan iklan atau sponsor.

\section{Televisi Republik Indonesia Provinsi Jambi}

TVRI berdiri pada 24 Agustus 1962 (berdasarkan SK Menpen RI No.20/SK/VII/61) ditandai dengan siaran perdana Asian Games ke IV di Stadion Utama Gelanggang Olah Raga Bung Karno. Pembangunan infrastruktur yang disiapkan oleh Pemerintah kala itu kawasan kompleks olahraga Senayan (Kampung Senayan, Petunduan, Kebun Kelapa dan Bendungan Hilir) serta pembangunan jalan baru yaitu Jalan M.H. Thamrin, Gatot Subroto, Jembatan Semanggi, hingga TVRI guna menunjang kebutuhan penyiaran turnamen.

Kehadiran TVRI disiapkan dalam waktu kurang dari sepuluh bulan. Menempati gedung yang semula dihajatkan sebagai Kampus Akademi Penerangan - Departemen 
Penerangan RI, di Gerbang Pemuda - Senayan Jakarta, program siaran disiapkan, dikemas dan dipancarluaskan memakai jaringan teresterial. Kemudian, pembangunan tahap berikut di luar Jawa, meliputi Sumatera, Kalimantan, dan Sulawesi. Sehingga, genap seperempat abad, infrastruktur penyiaran televisi sudah tersebar hampir di seluruh penjuru Nusantara. Secara kronologis status TVRI Tahun 1963 Berbentuk Yayasan Televisi Republik Indonesia (TVRI) berdasarkan Keputusan Presiden Nomor 215 Tahun 1963 tentang Pembentukan Yayasan Televisi Republik Indonesia. Merupakan stasiun televisi tertua di Indonesia dan satu-satunya televisi yang jangkauannya mencapai seluruh wilayah NKRI.

Memasuki era Reformasi bersamaan dengan dilikuidasinya Departemen Penerangan, melalui Keppres No.355/M/1999 tentang Pembentukan Kabinet Persatuan Nasional, maka status hukum TVRI mengambang. Tahun 1976 TVRI berubah status menjadi UPT (Unit Pelaksana Teknis) dibawah Departemen Penerangan. Namun Menteri Pendayagunaan Aparatur Negara melalui Kepmen No.I01/KEP/m.pan/1/2000 (5 Januari 2000) menugaskan pejabat dan pegawai di lingkungan Direktorat Televisi serta Unit Pelaksana Teknis di Jakarta dan Daerah untuk tetap melaksanakan tugas dan fungsi sesuai dengan ketentuan yang berlaku saat itu.Tahun 2000 status TVRI berubah menjadi PERJAN (Perusahaan Jawatan) berdasarkan Peraturan Pemerintah Nomor 36 Tahun 2000 tentang Pendirian Perusahaan Jawatan Televisi Republik Indonesia tanggal 7 Juni 2000. Setelah terbitnya Peraturan Pemerintah ini, TVRI memperoleh kejelasan status hukum yakni sebagai perusahaan jawatan yang menyelenggarakan kegiatan penyiaran televisi sesuai dengan prinsip-prinsip televisi publik, independen, netral, mandiri dan program siarannya senantiasa berorientasi kepada kepentingan masyarakat serta tidak semata-mata mencari keuntungan, dan menyelenggarakan kegiatan usaha jasa penyiaran publik dalam bidang informasi, pendidikan, dan hiburan serta usaha-usaha terkait lainnya yang dilakukan dengan standar yang tinggi. Secara kelembagaan berada di bawah pembinaan dan bertanggung jawab kepada Departemen Keuangan RI. Bulan September 2001, diterbitkan Peraturan Pemerintah No. 64 tahun 2001 tentang Pengalihan Kedudukan, Tugas dan Kewenangan Menteri Keuangan pada Perusahaan Perseroan (Persero), Perusahaan Umum (Perum), dan Perusahaan Jawatan (Perjan) Kepada Menteri Negara Badan Usaha Milik Negara. Dengan terbitnya PP Nomor 64 Tahun 2001 Pembinaan Perjan TVRI dari Departemen Keuangan dialihkan kepada 
Menteri Negara BUMN. Dalam Undang - Undang Nomor 32 Tahun 2002 tentang Penyiaran telah diatur segala hal mengenai penyiaran termasuk ditetapkannya TVRI sebagai Lembaga Penyiaran Publik yang didirikan dan dimiliki oleh Negara Republik Indonesia.

Lembaga Penyiaran Publik Televisi Republik Indonesia (LPP TVRI) berfungsi sebagai media informasi, pendidikan, hiburan yang sehat,kontrol dan perekat sosial, serta pelestari pemaju budaya bangsa dengan senantiasa berorientasi pada kepentingan publik dengan memperhatikan kemanfaatan dan perlindungan untuk kepentingan publik. Siaran TVRI diarahkan antara lain untuk:

1. Menjunjung tinggi pelaksanaan Pancasila dan

2. Undang-Undang Dasar NegaraRepublik Indonesia Tahun 1945;

3. Menjaga dan meningkatkan moralitas dan nilai-nilai agama serta jati diri bangsa

4. Meningkatkan kualitas sumber daya manusia;

5. Menjaga dan mempererat persatuan dan kesatuan bangsa;

6. Meningkatkan kesadaran dan ketaatan hukum dan disiplin nasional;

7. Menyalurkan pendapat umum serta mendorong peran aktif masyarakat dalam

8. Pembangunan nasional dan daerah serta melestarikan lingkungan hidup;

9. Mendorong peningkatan kemampuan perekonomian rakyat, mewujudkan

10. Pemerataan, dan memperkuat daya saing bangsa dalam era globalisasi;

11. Memberikan informasi yang benar, seimbang dan bertanggungjawab

12. Memajukan kebudayaan \& kearifan lokal

Dalam rangka menjalankan fungsinya sebagai Lembaga Penyiaran Publik (LPP) TVRI telah dibentuk Stasiun Penyiaran Daerah yang mempunyai tugas melaksanakan penyelenggaraan penyiaran televisi publik sesuai dengan kebijakan umum ataupun khusus yang ditetapkan Dewan Direksi. Saat ini baru terbentuk 28 Stasiun Penyiaran TVRI di ibukota Provinsi salah satunya adalah TVRI Stasiun Jambi yang diresmikan pada tanggal 15 April 1995. Pada awal berdirinya TVRI Jambi mengudara pada kanal VHF, siarannya saat itu tidak dapat menjangkau seluruh wilayah Provinsi Jambi. Namun sejak tahun 2011,Pemerintah Provinsi Jambi telah membangun transmisi UHF dan jaringan VPN IP. Sejak itu siaran TVRI dapat diterima oleh masyarakat Jambi di wilayah Kabupaten Kota. 
Topografi Wilayah Provinsi Jambi yang berbukit - bukit menyebabkan masih banyak daerah blank spot atau daerah yang tidak dapat menerima signal siaran TVRI Jambi. Pada umumnya mereka menggunakan antena parabola untuk menangkap siaran televisi melalui satelit. Akibatnya informasi pembangunan Jambi yang disiarkan melalui TVRI Jambi tidak diketahui oleh masyarakat di pelosok desa. Untuk kepentingan penyebarluasan informasi pembangunan di seluruh wilayah Jambi maka Pemerintah Provinsi Jambi telah menyewa transponder Telkom guna memperluas jangkauan siaran TVRI Jambi.

1. Penyelenggaraan Siaran

TVRI Stasiun Jambi mengudara pada kanal siaran UHF ( Ultra High Ferquency ) dan kanal Satelit.

a. Kanal UHF

Sebagai Stasiun Penyiaran Daerah TVRI Jambi berkewajiban merelay siaran TVRI Pusat sesuai pola acara yang telah ditentukan. Saat ini alokasi siaran yang diberikan kepada stasiun penyiaran daerah hanya 4 (empat) jam dari pukul 15.00 sampai dengan pukul 19.00 WIB. Secara berjaringan siaran TVRI Pusat dan Daerah dipancarluaskan melalui pemancar UHF yang tersebar di 9 (sembilan) wilayah di Provinsi Jambi yaitu :

1) Transmisi Jambi, kanal $45 \mathrm{UHF}$, daya pancar 2000 watt

2) Transmisi Sungai Penuh, kanal 22 UHF, daya pancar 500 watt

3) Transmisi Kayu Aro,kanal 10 VHF daya pancar 10 watt

4) Transmisi Bungo, kanal 36 UHF daya pancar 1000 watt

5) Transmisi Bangko, kanal 38 UHF daya pancar 1000 watt

6) Transmisi Tebo, kanal 26 UHF daya pancar 500 watt

7) Transmisi Sarolangun, kanal 50 UHF daya pancar 1000 watt

8) Transmisi Tungkal Ilir, kanal 36 UHF daya pancar 500 watt

9) Transmisi Tungkal Ulu, kanal 40 UHF daya pancar 500 watt Jaringan siaran ini dapat diterima oleh pemirsa melalui pesawat penerima dengan antena UHF. Dengan daya pancar yang ada siaran TVRI Jambi hanya dapat menjangkau wilayah ibukota Kabupaten/Kota dan tidak bisa diterima di pelosok desa.

b. Kanal Satelit

Layanan siaran satelit dapat membuka akses siaran yang sangat luas. Topografi Wilayah Provinsi Jambi yang berbukit - bukit menyebabkan masih banyak daerah blank 
spot atau daerah yang tidak dapat menerima signal siaran TVRI Jambi. Pada umumnya masyarakat menggunakan antena parabola untuk menangkap siaran televisi melalui satelit. Akibatnya informasi pembangunan Jambi yang disiarkan melalui TVRI Jambi tidak diketahui oleh masyarakat di pelosok desa. Untuk itu agar informasi Pembangunan Jambi dapat tersebar luas ke pelosok desa, mulai tahun 2013, Pemerintah Provinsi Jambi telah memfasilitasi penggunaan satelit untuk siaran TVRI Jambi. Siaran melalui satelit ini dapat menjangkau seluruh wilayah Propinsi Jambi, Nasional bahkan Internasional. Dengan demikian informasi pembangunan Jambi dapat tersebar luas dan harapan menuju Jambi Ekonomi Maju Aman dan Sejahtera dapat terwujud. Siaran TVRI Jambi melalui Satelit Telkom 1, Frequency 3743 Simbol Rate 3000,Polarisasi Horisontal, Audio PID 0033, Video PID 0034 , PCR PID 0034. Siaran ini hanya dapat diterima melalui antena Parabola.

\section{Strategi Humas TVRI Jambi dalam Mempromosikan Program}

Strategi pada hakikatnya adalah perencanaan Manajemen untuk mencapai suatu tujuan. Namun, untuk mencapai tujuan tersebut, strategi tidak berfungsi sebagai peta jalan yang hanya menunjukkan arah saja, tetapi harus menunjukkan bagaimana taktik operasionalnya. Demikian pula strategi komunikasi merupakan paduan dari perencanaan komunikasi (Communication Planning) dan manajemen komunikasi (Management Communication) untuk mencapai suatu tujuan. Untuk mencapai tujuan tersebut strategi komunikasi harus dapat menunjukkan bagaimana operasionalnya secara taktis harus dilakukan, dalam arti kata bahwa pendekatan (Approach) bisa berbeda sewaktu-waktu, bergantung kepada situasi dan kondisi. ${ }^{13}$

Untuk mengetahui strategi komunikasi yang dilakukan Humas dalam mempromosikan program acara TVRI Jambi, tentunya peneliti mengadakan wawancara langsung ke lapangan kepada narasumber yaitu Humas TVRI Jambi.

1) Strategi Public Relation berdasarkan Strategi S-O (Streght-Opportunity)

a) Strategi peningkatan peran dan fungsi humas sebagai mediator,komunikator serta public image maker yang lebih baik secara institusional hlm 29 .

${ }^{13}$ Uchjnana Effendy, Dinamika Komunikasi (Bandung : PT Remaja Rosdakarya, 2008), 
b) Strategi berbasis public/masyarakat dengan memanfaatkan SDM TVRI di seluruh pelosok nusantara dalam rangka mengedukasi publik tentang program acara TVRI dan mensosialisakan TVRI sebagai televisi pendidikan serta melakukan dengar pendapat tentang harapan publik terhadap TVRI

c) Strategi prioritas pendanaan bagi kegiatan kehumasan TVRI untul lebih intes terjun ke masyarakat dalam rangka mengkomunikasikasikan program TVRI dan mengakomodir keinginan, kebutuhan dan selera public

d) Strategi Promosi untuk mempublikasikan program dan kegiatan TVRI yang bermanfaat bagi public

e) Strategi Kemitraan berbasis media/organisasi lokal di seluruh wilayah nusantara dengan melibatkan seluruh karyawan yang juga bisa berperan sebagai humas bagi TVRI

f) Strategi focus program pendidikan yang sesuai dengan selera,kebutuhan dan harapan public tentang hadirnya tayangan pendidikan yang berkualitas

2) Strategi Public Relation berdasarkan strategi Weakness-Opportunity (WO)

a) Strategi pengadaan SDM,khususnya Kehumasan yang sesuai standar kompetensi Humas yang bisa menjalankan fungsi dan perannya dalam institusi TVRI

b) Strategi Pengembangan SDM untuk meningkatkan kualitas kinerja SDM yang lebih baik

c) Strategi restrukturisasi divisi kehumasan sebagai divisi yang lebih berdaya guna bagi manajemen /pengelola dalam menjalankan institusi TVRI sebagai televisi yang berbasis pendidikan yan maju dan berkembang

d) Strategi kemitraan dengan menjalin kerjasama dengan perusahaan,media,organisasi lainnya untuk meningkatkan kinerja dan kualitas program TVRI

e) Strategi promosi yang lebih kreatif, tepat guna dan tepat sasaran melalui eventevent yang bermanfaat bagi public, strategi iklan layanan masyarakat,launching websiteTVRI yang dapat diakses publik

f) Strategi Evaluasi program yang melibatkan humas sebagai analis opini public untuk terus menyesuaikan dengan kondisi pasar.

3) Strategi S-T (Strengths \& Threats) 
a) Strategi Komunitas Pemirsa Strategi berbasis komunitas pemirsa merupakan strategi komunikasi antara TVRI dengan publik untuk merespon dinamika pasar yang sangat dinamis. Komunitas yang dibentuk bisa berdasarkan hobi (komunitas sepeda onthel,komunitas moge,komunitas pencinta binatang, dll),profesi (komunitas guru,dokter,dll),tempat tinggal, dan lain-lain. Forum diskusi antar komunitas harus dilakukan secara peridik. Tujuannya adalah melibatkan komunitas/public dalam merencanakn program acara TVRI, sarana promosi dan komunikasi sehingga terjalin sinergi yang menguntungkan bagi eksistensi TVRI sebagai televisi pendidikan dan secara bertahap bisa tercipta brand image yang positif bagi TVRI sebagai televisi pendidikan.

b) Strategi Kemitraan dengan wartawan,koresponden, radio-radio lokal,media cetak serta lembaga-lembaga lainnya untuk mengedukasi pasar dan perecanaan program yang lebih berkualitas

c) Strategi Pembiayaan prioritas dan kemitraan

d) Strategi CSR (Customer Social Responsibility)

e) Strategi Transparansi Informasi dan Program:TVRI sebagai lembaga penyiaran publik harus menyajikan informasi dan program yang netral dan berimbang tanpa keberpihakan pada kepentingan pihak tertentu. Oleh karena itu setiap informasi dan program disajikan dapat dipertanggungjawabkan kepada publik. Publik juga bisa memberikan saran,/masukan, kritikan kepada pihak TVRI mengenai informasi/program TVRI.

4) Strategi S-W (Strengths \& Weakness)

a) Strategi Peningkatan SDM

b) Strategi Pengembangan infrastruktur dan teknologi modern. TVRI sebagai media public harus siap bersaing di pasar yang sangat kompetetif. Ketersediaan infrastruktur dan peralatan dengan tehnologi yang lebih modern akan meningkatkan kualitas pelayanan kepada public yang membutuhkan informasi serta program-program yang berkualitas,

c) Strategi Promosi: Promosi harus selalu dilakukan secara terus-menerus untuk bisa membangun image di benak publik. Strategi promosi yang bisa dilakukan antara lain: iklan layanan masyarakat yang ditayangkan di media cetak,media elektronik,media internet (media sosial: facebook,twitter,blog,website) yang 
berisi informasi tentang programprogram pendidikan TVRI kepada publik, pameran, event-event buletin TVRI, dan CSR.

d) Strategi Kemitraan: Kemitraan dengan lembaga-lembaga strategis bertujuan untuk membangun hubungan jangka panjang untuk membangun citra positif TVRI dan menanamkan informs positif pada masyarakat

Penelitian mewawancara PR LPP TVRI, beliau menyatakan bahwa:

[M]anusia pada tempatnya sudah berkomunikasi tanpa mempelajari ilmu komunikasi. Namun pandangan itu dinilai menempaatkan ilmu komunikasi pada posisi yang sangat sempit, sebab ia tidak melihat komunikasi sebagai suatu propesi yang bisa membantu diri seseorang dalam meningkatkan perannya sebagai anggota masyarakat, baik melalui hubungan antar manusia, maupun dalam meningkatkan keterampilannya (communication skills) dalam bentuk kreativitas yang bisa dijadikan sebagai lepangan kerja. ${ }^{14}$

\section{5) Strategi Promosi}

Promosi adalah kegiatan pemasaran yang umum dilakukan tenaga pemasar untuk memberikan informasi suatu produk dan mendorong konsumen agar melakukan pembelian produk tersebut. Cara dan media promosi ada banyak sekali, bahkan metode promosi selalu berkembang dari waktu ke waktu. Masyarakat awam sering mendengar dan membaca promosi, baik itu promosi dalam bentuk media cetak, baliho, billboard, radio, televisi, dan internet. Mereka yang memiliki minat yang sesuai dengan iklan atau promosi tersebut umumnya akan membaca informasi yang ada di promosi tersebut lebih lama.

Penelitian mewawancara Humas LPP TVRI, beliau menyatakan bahwa:

[B]ahwa media massa mau menerima sumbangan berita atau informasi serta artikel dan tulisan dari pihak luar, sepanjang tulisan tersebut memiliki nilai berita yang cukup tinggi untuk dapat dimuat. Dalam definisi tersebut tidak disebutkan akan adanya kewajiban untuk membayar atau membeli semacam ruang dan waktu tertentu seperti dalam iklan. Artinya, jika suatu organisasi/perusahaan, perorangan, bisa mengemas sebuah cerita atau artikel tentang kegiatan-kegiatan yang dilakukan organisasinya menjadi sebuah tulisan yang bernilai berita cukup tinggi maka media massa tidak akan ragu-ragu untuk memuatnya, tanpa dipungut biaya apapun.Hal inilah yang menyebabkan Publisitas dikategorikan sebagai metode komunikasi massayang tidak terkontrol, karena diliput tidaknya sebuah berita oleh media massa benar-benar tergantung dari layak muat tidaknya sebuah berita. Walaupun dibandingkan dengan iklan tampak bahwa publisitas kurang pasti sifatnya, namun dari aspek kredibilitas

\footnotetext{
${ }^{14}$ Agus selaku PR LPP TVRI Jambi, wawancara dengan peneliti 22 -februari-2020
} 
pesan publisitas biasanya dianggap memiliki nilai yang lebih tinggi. Hal ini disebabkan adanya persepsi di masyarakat, bahwa iklan dianggap sebagai sebuah pesan yang persuasif serta penuh dengan bujuk rayu mengajak khalayak untuk membeli sebuah produk. Lain halnya jika sebuah cerita atau informasi muncul di media massa sebagai berita. Berita dipersepsi sebagai suatu kejadian yang faktual, yang benar terjadi, dan karenanya dianggap lebih jujur dan dapat dipercaya.

\section{6) Strategi Publisitas}

Fungsi publisitas yaitu sebagai kegiatan dalam dunia politik dikenal salah satunya adalah publisitas politik. Publisitas ini merupakan upaya mempopulerkan diri kandidat atau institusi partai yang akan bertarung dalam pemilu. Yang diberitakan/menginformasikannya mellalui mediamassa. Ada empat bentuk publisitas yang dikenal dalam khazanah komunikasi politik.Pertama, dikenal sebagai pure publicity yakni mempopulerkan diri melalui aktivitas masyarakat dengan setting sosial yang natural atau apa adanya. Misalnya saja, bulan Ramadhan dan Idul Fitri merupakan siklus aktivitas tahunan sehingga menjadi realitas yang apa adanya. Kandidat/seseorang, organisasi bisa memanfaatkan kesempatan tersebut untuk memasarkan dirinya. Misalnya dengan mengucapkan "Selamat Menjalani Bulan Ramadhan" atau "Selamat hari Raya idul fitri" dengan embel-embel nama atau photo kandidat. Semakin banyak jenis bentuk pure publicity yang siarkan di media massa, maka akan semakin populer sesorang atau organisasi tersebut. Kedua, free ride publicity yakni publisitas dengan cara memanfaatkan akses atau menunggangi pihak lain untuk turut mempopulerkan diri. Misalnya saja dengan tampil menjadi pembicara di sebuah forum yang diselenggarakan pihak lain, menjadi sponsor gerakan anti narkoba, turut berpartisipasi dalam pertandingan olahraga di sebuah daerah kantung pemilih dan lain-lain. Ketiga, tie-in publicity yakni dengan memanfaatkan extra ordinary news (kejadian sangat luat biasa). Misalnya saja peristiwa tsunami, gempa bumi atau banjir bandang. Kandidat dapat mencitrakan diri sebagai orang atau partai yang memiliki kepedulian sosial yang tinggi sehingga imbasnya memperoleh simpati khalayak. Sebuah peristiwa luar biasa, dengan sendirinya memikat media untuk meliput. Sehingga partisipasi dalam peristiwa semacam itu, sangat menguntungkan kandidat. Keempat, paid publicity sebagai cara mempopulerkan diri lewat pembelian rubrik atau program di media massa. Misalnya, pemasangan advertorial, Iklan spot, iklan kolom, display atau pun juga blocking time 
program di media massa. Secara sederhananya dengan menyediakan anggaran khusus untuk belanja media.

Penelitian mewawancara Humas LPP TVRI, beliau menyatakan bahwa:

[F]ungsi publisitas tidak lepas dari fungsi komunikasi massa. Sejumlah upaya mencoba mensistimasisasikan fungsi utama komunikasi massa, yang pada mulanya dimulai oleh Lasswell (1948) yang memberikan ringkasan/kesimpulan mengenai fungsi dasar komunikasi sebagai berikut: pengawasan lingkungan; pertalian (korelasi) bagian-bagian masyarakat dalam memberikan respon terhadap lingkungannya; transmisi warisan budaya. Fungsi pengawasan sosial merujuk pada upaya penyebaran informasi dan interpretasi yang obyektif mengenai berbagai peristiwa yang terjadi di dalam dan di luar lingkungan sosial dengan tujuan kontrol sosial agar tidak terjadi hal-hal yang tidak diinginkan. Fungsi korelasi sosial merujuk pada upaya pemberian interpretasi dan informasi yang menghubungkan satu kelompok sosial dengan kelompok sosial lainnya atau antara satu pandangan dengan pandangan lainnya dengan tujuan mencapai konsensus. Fungsi sosialisasi merujuk pada upaya pewarisan nilai-nilai dari satu generasi ke generasi lainnya, atau dari satu kelompok ke kelompok lainnya.

\section{E. Kendala Mempromosikan Program Acara LPP TVRI Jambi}

\section{Kurangnya Sumber Daya Manusia (SDM)}

Sumber daya manusia (SDM) merupakan unsur yang strategis dalam menentukan sehat atau tidaknya suatu organisasi. Manajemen SDM aparatur memiliki fungsi penting yaitu mendorong agar setiap organisasi pemerintah dapat mencapai visi, misi dan tujuan organisasi.Organisasi penyiaran sebagaimana organisasi lainnya memiliki memberikan pengaruh yang dalam bagi pengembangan sumber daya manusia. Lebih jauh, penilaian kinerja berbasis sasaran kerja individu merupakan suatu rangkaian yang berawal dari penetapan tolak ukur yang meliputi aspek kuantitas, kualitas, waktu dan biaya dari setiap kegiatan tugas pokok jabatan. Sistem penilaian kinerja yang dirancang lebih bersifat terbuka sehingga diharapkan dapat meningkatkan motivasi dan produktivitas kerja serta menciptakan hubungan interaksi antara pejabat penilai dengan pegawai yang dinilai dalam rangka objektivitas penilaian dan untuk mendapatkan kepuasan kerja setiap pegawai. Lembaga penyiaran publik TVRI yang memiliki pegawai dengan penilaian kerja DP3 harus dikembangkan dengan penilaian kinerja berbasis Sasaran Kerja Individu. Karena produktivitas karya-karya jurnalistik dan artistik yang unik dari TVRI harus diterima khalayak luas untuk menjunjung tinggi Idealisme dan Martabat 
Bangsa Indonesia. Dengan program-program yang berdasarkan ke-ilmuan, seni modern dan berakar pada Budaya Indonesia.

Sumber daya manusia (SDM) merupakan unsur yang strategis dalam menentukan sehat atau tidaknya suatu organisasi. Manajemen SDM aparatur memiliki fungsi penting yaitu mendorong agar setiap organisasi pemerintah dapat mencapai visi, misi dan tujuan organisasi. Organisasi penyiaran sebagaimana organisasi lainnya memiliki memberikan pengaruh yangdalam bagi pengembangan sumber daya manusia. Lebih jauh, penilaian kinerja berbasis sasaran kerja individu merupakan suatu rangkaian yang berawal dari penetapan tolok ukur yang meliputi aspek kuantitas, kualitas, waktu dan biaya dari setiap kegiatan tugas pokok jabatan. Sistem penilaian kinerja yang dirancang lebih bersifat terbuka sehingga diharapkan dapat meningkatkan motivasi dan produktivitas kerja serta menciptakan hubungan interaksi antara pejabat penilai dengan pegawai yang dinilai dalam rangka objektivitas penilaian dan untuk mendapatkan kepuasan kerja setiap pegawai. Lembaga penyiaran publik TVRI yang memiliki pegawai dengan penilaian kerja DP3 harus dikembangkan dengan penilaian kinerja berbasis Sasaran Kerja Individu. Karena produktivitas karya-karya jurnalistik dan artistik yang unik dari TVRI harus diterima khalayak luas untuk menjunjung tinggi Idealisme dan Martabat Bangsa Indonesia. Dengan program-program yang berdasarkan ke-ilmuan, seni modern dan berakar pada Budaya Indonesia.

\section{Persaingan denga Televisi Swasta}

Meski TVRI milik negara dan memiliki program acara yang bagus-bagus mulai dari pendidikan, anak-anak, olahraga hingga berita dan lainnya, bukan berarti televisi ini menjadi yang diutamakan oleh masyakarakat Indonesia. Buktinya saja, sejak kemunculan televisi-televisi swasta, nama TVRI mulai tenggelam sebab masyarakat lebih tertarik dengan program-program acara yang disuguhkan oleh televisi swasta.

Direktur Program dan Berita TVRI mengungkapkan, terdapat beberapa hal yang menyebabkan TVRI kalah saing, di antaranya Sumber Daya Alamnya yang kurang memadai, teknologi yang digunakan sudah tua dan tidak mau mengikut revolusi digital. Alhasil program acara yang dihasilkan standar dan pastinya tidak ada nilai jual. 


\section{Teguran dari KPI}

Namanya juga media televisi, pastinya tak luput dari pengawasan pihak Komisi Penyiaran Indonesia (KPI). Demi menjaga tugas TVRI berjalanan sesuai dengan aturan yang berlaku, KPI pun sempat melakukan beberapa kali teguran kepada pihak TVRI karena siaran yang tidak sesuai. Berikut daftar teguran yang diterima TVRI oleh KPI.

\section{E. Upaya HUMAS TVRI Jambi dalam Mempromosikan Program}

\section{Kerja Sama}

Kerjasama adalah pengaturan kemitraan saling menguntungkan yang dilakukan secara sukarela oleh dua bidang usaha atau lebih. Kerjasama ini menjadi hal yang menguntungkan karena beberapa permasalahan menjadi lebih ringan. Selain itu, kerjasama tidak hanya soal mencari dana saja. Beberapa pebisnis lebih suka menjalin relasi yang menguntungkan dengan sesama kompetitor. Daripada bersaing yang akhirnya membuat stres, lebih baik saling melengkapi hal-hal yang tidak dimiliki. Terlebih saat darurat. Misalnya seorang suplier ikan. Ketika pada suatu hari ia kehabisan stok, ia bisa mencari ikan ke suplier lainnya.

Menjalin Kerjasama Lembaga Penyiaran Publik memang harus dapat memberikan informasi kepada masyarakat dengan tanggung jawab yang tinggi dan dekat dengan masyarakat. Menjalin kerjasama dengan berbagai pihak menjadi satu kesatuan penting yang harus dilaksanakan oleh industry media islam. Media tidak hanya memberikan informasi kepada masyarakat namun juga memberikan inspirasi kepada masyarakat. Di 2019, TVRI banyak melakukan kerjasama dalam bidang progam diantaranya dengan Discpvery, Djarum untuk rumah bulutangkis mulai dari All England, Sudirman Cup, World Championships, China Open, Malaysian Open, Japan Open, Denmark Open, Frensh Open, Fuzhou China Open dan World Tour Final. Sebuah kegiatan yang bertemakan TVRI Care to Pondok Pesantren adalah langkah untuk pengembangan menuju idustri media islam. Disanalah peran insan media tidak hanya meliput namun juga menyalurkan ilmu jurnalistik kepada generasi generasi penerus bangsa. Dapat diamati relita yang ada tugas dari para jurnalis dan wartawan selama ini hanya datang di tempat kejadian kemudian mengambil gambar dan meliput informasi kemudian di tayangkan di televisi. Tentu dengan hadirnya industry media islam ini, 
seorang wartawan, maupun reporter juga mampu menjadi pendidik sebagaimana membagikan ilmu kepada masyarakat.

\section{Modifikasi Produk}

Strategi lain yang dibuat kalangan industri pertelevisiaan adalah melakukan modifikasi produk dengan perbaikan kualitas produk yang sudah ada. Inovasi menjadi kunci keberhasilan dalam strategi modifikasi produk. Desain dan kemasan menarik tentu dapat menarik konsumen dan hal ini dapat diterapkan di media televisi. Dalam beberapa tahun terakhir, media televise sangat aktif mengubah tampilan visual produknya, baik memodifikasi tampilan audio, visual maupun actor yang ada dalam progam acara yang ditayagkan di televisi. Sebagaimana industri media islam yang masih sulit dikonsep namun secara mutlak harus mengikuti standar ataupun ketentuan yang sesuai dengan Al-Quran maupun hadits. Serta kini masyarakat membutuhkan sebuah acara yang akan indah jika lebih menghibur karena saat ini televisi tidak cukup jika hanya dijadikan media informasi saja, namun juga menjadi media hiburan. Apapun yang lebih menghibur tentu itulah yang menjadi pilihan masyarakat. Baik berupa sinetron yang tidak mendidik maupun talkshow yang hanya sebatas guyonan namun memberikan hiburan bagi penonton justru itulah yang dipilih. Sedangkan, Industri media islam harus mampu memberikan informasi yang sekaligus mengajak masyarakat untuk mendekatkan diri kepada Allah. Dengan menghadirkan progam progam baru yang dikemas dalam desain logo baru, tentu akan dapat memberikan wajah wajah baru untuk perkembangan industry media islam yang kedepan akan menjadi media yang terbaik utuk dikonsumsi oleh masyarakat. Inilah yang menjadi sebuah tantangan bagi industri media islam yakni menyiarkan d’akwah namuan juga dapat memberikan kesenangan dan motivasi kepada masyarakat.

\section{Membuat Produk Baru}

Berdasarkan laporan, Tempo interaktif pada tanggal 2 ktober 2010, dinyatakan bahwa dalam riset yang dilaksanakan di 46 negara dan melibatkan 50 ribu pengguna situs jejaring sosial ini juga diketahui terdapat sebanyak $61 \%$ respondennya mengakses 
internet setiap hari. Sementara porsi untuk menonton televisi, mendengarkan radio dan membaca surat kabar masing-masing sebesar 54\%, 36\%, dan 32\%. Menurut Chief Development Officer TNS Mathew Froggatt, mengungkapkan bahwa internet telah menjadi bagian terpenting dalam kehidupan di abad 21. Hasil penelitian yang dilakukan oleh Chrap (2000) mengatakan bahwa 50\% rumah di amerika dapat dikatakan berhubungan melalui internet setiap jamnya. Internet mengalami pertumbuhan dengan pesat sekitar lebih dari 100\% per tahun.12 Munculnya internet ini yang mengususng media online menyebabkan masyarakat saat ini lebih memilih media online daripada media televise, karena media online lebih cepat diakses dan efektif serta masyarakat dapat melihat secara cepat dan interaktif sifatnya dibandingkan dengan televisi. Hal inilah yang menjadi persaingan bagi media televisi. Oleh sebab itu langkah dari media televise untuk meningkatkan brandingnya harus melakukan konvergensi yakni penggabungan antara media online dengan media massa atau menggabungkan beragai media berbeda menjadi satu. Dengan ini Media mampu menggandeng berbagai aplikasi media online takni media instagram maupun media youtube dengan berbagai progam acara yang dimiliki. Melalui media internet, juga melakukan interaksi kepada publik bukan hanya sekedar menyebarkan informasi.

\section{Pengelolaan SDM}

Sumber Daya Manusia (SDM) atau man power merupakan potensi yang ada dalam diri manusia untuk mewujudkan peranna sebagai makhluk sosial yang adaptif dan transformative. Artinya manusia mampu mengelola dirinya serta seluruh potensi yang terkandung di alam.Sebagai industri media islam yang mengedepankan kedamaian dan nilai nilai dakwah tentu menjadi hal penting untuk diberikan pada karyawan yang berada di lingkungan lembaga tersebut.

Adapun yang dapat ditunjukka yakni memberikan pelatihan khusus kepada karyawan bukan mencari karyawan yang berpotensi saja tanpa diawali dengan pembinaan khusus, sedangkan ilmu yang dierikan selain praktik, akademisi juga ilmu keagamaan yang berkaitan dalam kode etik fiqih jurnalistik agar karyawan mampu mengelola. 


\section{F. Penutup}

Berdasarkan uraian diatas, ada dua kesimpulan: pertama, strategi Publik Relations Strategi pada hakikatnya adalah perencanaan (Planning) Manajemen (Menegement) untuk mencapai suatu tujuan. Namun, untuk mencapai tujuan tersebut, strategi tidak berfungsi sebagai peta jalan yang hanya menunjukkan arah saja, tetapi harus menunjukkan bagaimana taktik operasionalnya,Komunikasi secara bahasa dalam bahasa Inggris dikenal dengan communication. Komunikasi juga dikenal dengan proses penyampaian pesan oleh komunikator kepada orang yang yang menerima pesan (komunikan), Periklanan adalah hal yang tidak bisa dilepaskan dari dunia maketing. menyatakan bahwa "periklanan adalah segala bentuk penyajian dan promosi ide, barang, atau jasa secara non personal oleh suatu sponsor tertentu yang memerlukan pembayaran, Promosi adalah kegiatan pemasaran yang umum dilakukan tenaga pemasar untuk memberikan informasi suatu produk dan mendorong konsumen agar melakukan pembelian produk tersebut,Publisitas merupakan istilah yang popular bukan saja dalam dunia PR tapi dalam dunia sehari-sahari. Dalam pandangan tidak ada batasan untuk ruang kreatif kegiatan publisitas itu, selain batasan-batasan etika, Corporate identity adalah bagian identitas yang bersifat fisik, sehingga bisa disebut sebagai visual identity. Bentuk paling sederhana dari visual identity ini adalah simbol; Kedua, kendala publik relations dalam mempromosikan program acara di LPP TVRI Jambi yaitu: kurangnya sumber daya manusia (SDM), Kalah Saing dengan Hadirnya Televisi Swasta, Keuangan yang Tak Membaik dan Sarang Korupsi. Sempat Kena Teguran dari KPI. Upaya publik relations dalam mempromosikan program acara di LPP TVRI Jambi yaitu: Kerja Sama, Modifikasi, Produk Membuat Produk Baru, Pengelolaan SDM. Peneliti menyarankan LPP TVRI untuk mengevaluasi peran sebagai expert prescriber dan fasilitator communication oleh divisi Humas, agar dapat menentukan strategi yang tepat untuk mengatasi tidak meratanya semangat rebranding di pihak internal. Selain itu, untuk melihat strategi rebranding LPP TVRI berhasil atau tidak di masyarakat, bidang Puslitbang dapat melakukan survei kepada publik. 


\section{Daftar Pustaka}

Bungin Burhan, Analisis Data PenelitianKualitatif Pemahaman Filosofis dan Metodologis ke Arah Penguasaan Model dan Aplikasi, Jakarta: PT Raja Grafindo Persada, 2012.

Coulson, Definisi public relations, Jakarta: Balai Pustaka, 2005.

Dewan Penerjemah, Al-Qur'an dan Terjemahnya Jakarta: CV Darus Sunnah, 2000.

H.A.W.Widjaja, Komunikasi dan hubungan masyarakat, Jakarta: Bumi aksara, 2010.

Jefskin Frenk, Strategi public relations edisi kedua, Jakarta: Gelora Aksara Pratama, 1995.

Santoso Imam, Pengertian program acara, Jakarta: 2010.

Lexy J. Moleong, Metodologi Penelitian Kualitatif, Bandung: Remaja Rosdakarya, 2000.

Djamalaudin Malik, Komunikasi Persuasif, Bandung: Remaja Rosdakarya, 1994.

David R fred, Manajemen Strategi Konsep, Jakarta: Prehalindo, 2003.

Effendi Uchjana Onong, IImu Komunikasi: Teori dan Praktek Bandung: Remaja Rosda Karya, 2013.

Gunawan Imam, Metode Penelitian Kualitatif: Teori dan Praktik, Jakarta:Bumi Aksara, 2013. Ilmu Komunikasi Teori dan Praktek Bandung: PT. Remaja Rosdakarya, 1992.

_ Ilmu Teori Dan Filsafat Komunikasi Bandung: PT Citra Aditya Bakti, 2003. Dinamika Komunikasi Bandung: PT Remaja Rosdakarya, 2008. Moleong J Lexy, Metode penelitian Kualitatif, Bandung : Remaja Rosdakarya, 2005. Mulyana Deddy, Ilmu Komunikasi Suatu Pengentar Bandung: Remaja Rosdakarya, 2005. 
Nawawi, Hadari Manajemen Strategi Organisasi Non-Profit Bidang Pemerintahan Ilustrasi di bidang Pendidikan Yogyakarta: Gadjah Mada Universitas Press, 2000.

Tim Penyusun Kamus Pusat Pembinaan dan Pengembangan Bahasa, Kamus Besar Bahasa Indonesia (KBBI) Edisi Kedua Jakarta: Balai Pustaka, 1994.

Wiryanto, Pengantar Ilmu Komunikasi Jakarta: PT Grasindo, 2004.

Arif suriansyah selaku Pembina LPP TVRI Jambi Wawancara dengan peneliti 10Maret-2020. LPP TVRI Jambi Rekaman Audio.

Agus selaku PR LPP TVRI Jambi Wawancara dengan peneliti 10-Maret-2020. LPP TVRI Jambi Rekaman Audio.

Meinurita selaku KASUBAG Umum LPP TVRI Jambi Wawancara dengan peneliti 10-Maret-2020. LPP TVRI Jambi Rekaman Audio. 